\title{
Packaging waste in Poland - current status and perspective
}

"There is nothing permanent except change"

Heraclitus

\section{Introduction}

Joining the European Union, Poland committed to observe all directives and regulations that function and with passing time will be changed or revised. In the last 10 years of participation in the system you will notice a big change especially in the field of waste management. Waste management is a burning issue not only in Europe but around the world, because the increase in the amount of waste does not bring us closer to the lofty principles of sustainable development, strategies for sustainable consumption and production (06.Sustainable... 2006) and the Roadmap to a Resource Efficient Europe (COM (2011) 571) but on the contrary - recede.

The purpose of the new directive of 2 July 2014. COM (2014) 397 final, 2014/0201 (COD), amending waste directive 2008/98/EC, packing 94/62/EC on the landfill of waste 1999/31/EC, car 2000/53/EC on batteries

Ph.D. Eng. Joanna Zarębska University of Zielona Góra Faculty of Economics and Management and accumulators 2006/66/EC and waste of eclectic and electronic equipment 2012/19/ $\mathrm{EU}$, is to increase the efficiency of waste management. As wecan read in the application “European Union's economy currently 
loses a significant amount of potential recyclables that are in the waste streams. About 2.5 billion tons of waste was made in 2011 within the EU. Only $40 \%$ of municipal waste generated in the EU were recycled, $37 \%$ was landfilled and 23\%was burned, with about 500 million tons of waste could be recycled or reused. EU loses significant opportunities to increase resource efficiency and creating an economy based on closed-circuit, leading to economic growth and job creation, which would result in reduced greenhouse gas emissions and dependence on imported raw materials economy "(Directive 2014, p. 2).

This conclusion highlights the large disparities in the implementation of regulations between Member States. For example, in 2011, six Member States landfilled less than 3\% of municipal waste, 18 countries landfilled more than $50 \%$ of municipal waste, and some even more than $90 \%$. Moreover, despite the fact that municipal waste account for about $7-10 \%$ of the total waste generated in the EU; this waste stream is diverse, and the way of managing of them testifies of the quality of the entire waste management system in the country. Challenges for municipal waste management (especially packaging) are result of the large diversity and the mixed composition of the waste. Moreover, the direct neighborhood of generated waste and residents and their exposition to the public view is also a problem.

Effective waste management requires the creation of a system which will include (EEA Report No 2/2013; Direktive 2014):

- more efficient than before collecting segregated waste "at source”,

- active involvement of citizens and companies in the recovery and recycling of municipal waste,

- infrastructure adapted to the diverse composition of the waste,

- the development of the municipal waste management financing system.

The new directive highlightens that countries which have created effective systems for municipal waste management, usually achieve better results in terms of waste management in general. Therefore, in Poland in 2012, The Act amending the Act on maintaining cleanliness and order in municipalities and certain other acts (Journal of Laws 2012, pos. 391), which after 18 months of adaptation (from 1 July 2013), introduced new rules for waste collection, especially the obligation to conclude a contract with the company that exports waste collection from residents. Next the Waste Act of 14 December 2012 (Journal of Laws 2013, pos. 21, as amended) was shown, the Law on packaging and packaging waste of 13 June 2013 (Journal of Laws 2013, pos. 888). These changes should lead to a greater conversion of municipal waste in resources, 
which in turn contribute to more effective resource management, resourceefficient and closed circulation in the economy.

The purpose of this article is to present legislative changes resulting from the alignment with the EU and the analysis of quantitative data on the segregation and recycling of packaging waste in Poland in the years 2010-2012. In addition, the results of research, whose aim was to answer the question of how changing consumer trends influence the implementation of the requirements of the revised laws and future implementation of the Directive COM (2014) 397 final. The research is particularly important because it shows the relationship between the changing trends in consumption, social habits, and the changing economic environment. Not all people want changes, especially if they require them physical, financial or time commitment. Sometimes only the financial stimulus and benefit perspective changes consumer behavior.

\section{Legal requirements concerning the management of packaging wastes in Poland and the level of their implementation}

After Poland joined EU structures, our legislation on waste management is continuously adapted to changes of the Community. The existing requirements for recovery and recycling of packaging waste (recovery rate of at least $60 \%$ by weight and the level of recycling between 55\% and 80\%) were initially introduced by the Act of 11 May 2001 on Packaging and packaging waste, and then revised with next amendments (consolidated text of the Act - Journal od Laws, 2005 No. 175, pos. 1458, as amended) and finally the introduction of the Law on packaging and packaging waste of 13 June 2013 (Journal of Laws 2013, pos. 888). However, as first appeared, the waste act of 14 December 2012. (Journal of Laws 2013, No. 0, pos. 21), which does not take into account the R14 and R15 recovery processes, and to demonstrate the recovery of packaging waste, it had to be subjected to recovery processes R1 to R9 and R13, recycle - R2 to R9. According to the law by the marshal of the province companies registered in the database are required to submit only two reports:

1) concerning the management of packaging and packaging waste,

2) concerning waste management.

The law on packaging and packaging waste takes into account these changes introduced by the Act on Waste, and also assumes (Law on packaging... 2013; Zarębska 2013, p. 28-34):

- mandatory external audit units involved in recycling and waste recovery and exporting of a weight exceeding $400 \mathrm{Mg}$ per year (more in the regulation concerning EMAS), 
- release packaging of plant protection products from the obligation to pay a deposit,

- a change in exemptions from product charges,

- changing the organization of recovery (eg. allocate 5\% of revenues on environmental education).

However, is not the end of changes, because the European Community on July 2, 2014 introduced a new Directive COM (2014) 397 final, which increases the minimum level in the preparation of packaging waste for reuse and recycling, which should be reached by the end of 2020 , 2025, and 2030 (see table 1). Paragraph $1 \mathrm{~b}$ was added in this directive, saying that "if the package is made up of different materials, the calculation of the objectives specified in Art. 6 paragraph 1 point f)-k) any material should be considered separately". This notation applies to, inter alia, composite packaging, for example: cartons for juice, nectar, milk whose classification, recovery and recycling already in the current national conditions is difficult to achieve.

Table 1. The level of recycling and preparation of packaging waste for reuse

\begin{tabular}{|c|c|c|c|c|c|c|c|}
\hline \multirow{3}{*}{ PACKAGING TYPE } & \multicolumn{7}{|c|}{ LEVELS TO THE END OF THE YEAR [IN \%] } \\
\hline & 2007 & 2010 & 2014 & 2020 & 2020 & 2025 & 2030 \\
\hline & \multicolumn{4}{|c|}{ EXISTING NATIONAL LEVELS } & \multicolumn{3}{|c|}{$\begin{array}{c}\text { NEW LEVELS } \\
\text { ACCORDING TO COM } \\
2014\end{array}$} \\
\hline Total & 25 & 38 & $55-80^{1)}$ & 56 & 60 & 70 & 80 \\
\hline Paper and cardboard packaging & 48 & 54 & 60 & 61 & 85 & 90 & 90 \\
\hline Plastic packaging & 25 & 18 & 22,5 & 23,5 & 45 & 60 & 60 \\
\hline Glass & 38 & 49 & 60 & 61 & 70 & 80 & 90 \\
\hline Ferrous metals & 20 & 35 & 50 & 51 & 70 & 80 & 90 \\
\hline Aluminum & 40 & 45 & 50 & 51 & 70 & 80 & 90 \\
\hline Wood & 15 & 15 & 15 & 16 & 50 & 65 & 80 \\
\hline
\end{tabular}

Does not apply to packaging items in a direct contact with medical products defined in the regulations of the Pharmaceutical law (Journal of Laws 2008. No. 45, item. 271, as amended).

Source: author's own research based on study based on: Act ...2001 (Journal of Laws 2007, No. 90, item. 607, as amended.); Act ...2014 (Journal of Laws 2013, pos. 888),

Directive COM (2014) 397 final 
Raising levels of recycling and preparation of packaging waste for re-use will result in even greater difficulties than ever in achieving these goals of packaging waste management in Poland. Regulation of the Minister of Environment of 29 May 2012 introduces a reduction in the levels of recycling, preparation for re-use and recovery of other methods of some fraction of municipal waste, but in 2014 changes again for the higher in two subsequent regulations that divide waste into: household packaging waste and composite packaging material divided by the type of predominant material (recovery, recycling), which illustrates the summary in table 2 .

Table 2. The level of recycling and preparation for re-use and recovery of packaging waste in the years 2012-2020

\begin{tabular}{|c|c|c|c|c|c|c|c|c|c|}
\hline \multirow{3}{*}{$\begin{array}{l}\text { Paper, } \\
\text { metal, } \\
\text { plastic, } \\
\text { glass }{ }^{1}\end{array}$} & \multicolumn{9}{|c|}{ THE LEVEL OF RECYCLING AND PREPARATION FOR REUSE [\%] } \\
\hline & 2012 & 2013 & 2014 & 2015 & 2016 & 2017 & 2018 & 2019 & 2020 \\
\hline & 10 & 12 & 14 & 16 & 18 & 20 & 30 & 40 & 50 \\
\hline re-use & \multirow{2}{*}{\multicolumn{2}{|c|}{ For households }} & 32 & 35 & 38 & 41 & 44 & 47 & 50 \\
\hline recycling & & & 32 & 35 & 38 & 41 & 44 & 47 & 50 \\
\hline re-use & \multirow{2}{*}{\multicolumn{2}{|c|}{$\begin{array}{l}\text { Composite packaging } \\
\text { by the type of } \\
\text { predominant mat. }\end{array}$}} & 14 & 20 & 25 & 30 & 40 & 50 & 61 \\
\hline recycling & & & 10 & $16-18$ & $16-20$ & $16-30$ & $16-40$ & $16-50$ & $16-61$ \\
\hline
\end{tabular}

${ }^{1)}$ Levels are calculated total for all of the specified fraction of municipal solid waste.

Source: author's own research based on: Regulation of the Minister of Environment (Journal of Law 2012, pos. 645), Regulation of the Minister of Environment (Journal of Law 2014, pos.

412), Regulation of the Minister of Environment (Journal of Law 2014, pos. 618)

Various kinds of packaging type: cartons, cups, tubes, bags, vials, bottles, cans, jars, cans and shopping bags are up to $60 \%$ of the European landfills. In Poland, the amount of packaging waste in the waste mass is estimated to be about $30 \%$ by weight and $50 \%$ by volume, although in the literature can be found estimates of the volume - 50\% by weight and 70\% by volume (Korzeniowski, Skrzypek, Szyszka 2001, p. 29). According to the Central Statistical Office's data in 2012 y. 9,581 million tons of municipal waste were collected (in 2011 - 9.83 million tons, in $2010-10.04$ million tons) to 12,085 million tons of generated 
waste (in 2011 - 12.129 million tons, in 2010 - 12.04 million tons), including (according to the Central Statistical Office 2013, p. s. 353-355):

- 8.575 million tons were mixed wastes (so 222,5 kg/R/year),

- 1.005 million tons - selected waste intended for recycling. The per capita falls $248.6 \mathrm{~kg} /$ Resident/year of municipal waste collected. Only 0.718 million tons of municipal waste were segregated by residents at their home, while 6,102 million $\mathrm{Mg}$ are mixed waste, of which only 0.44 million ton of waste were segregated. The collected waste was processed a total of 8,136 million tons (in 2011 - 8,72 million Mg), of which:

- 0.927 million tons (in 2011-1.64 million Mg) - disposed of by the biological and bio-mechanical method,

- 0.051 million tons (in 2011 - 0.1 million $\mathrm{Mg}$ ) - disposed of thermally,

- 7,158 million tons (in 2011 - 6.98 million Mg) - deposited in landfills.

Converting the above data it can be clearly stated that $74.7 \%$ of total collected waste goes to the landfills (collected, for processing - almost 88\%), which indicates progress, but they still lack an efficient system of municipal waste management. Analyzing the past few years, there is a lack of progress in the collection and processing of waste, the processing that would be consistent with the waste hierarchy according to EU guidelines. Similar conclusions can be drawn by analyzing figure 1, which presents the achieved level of recovery and recycling of packaging waste in 2010-2012.

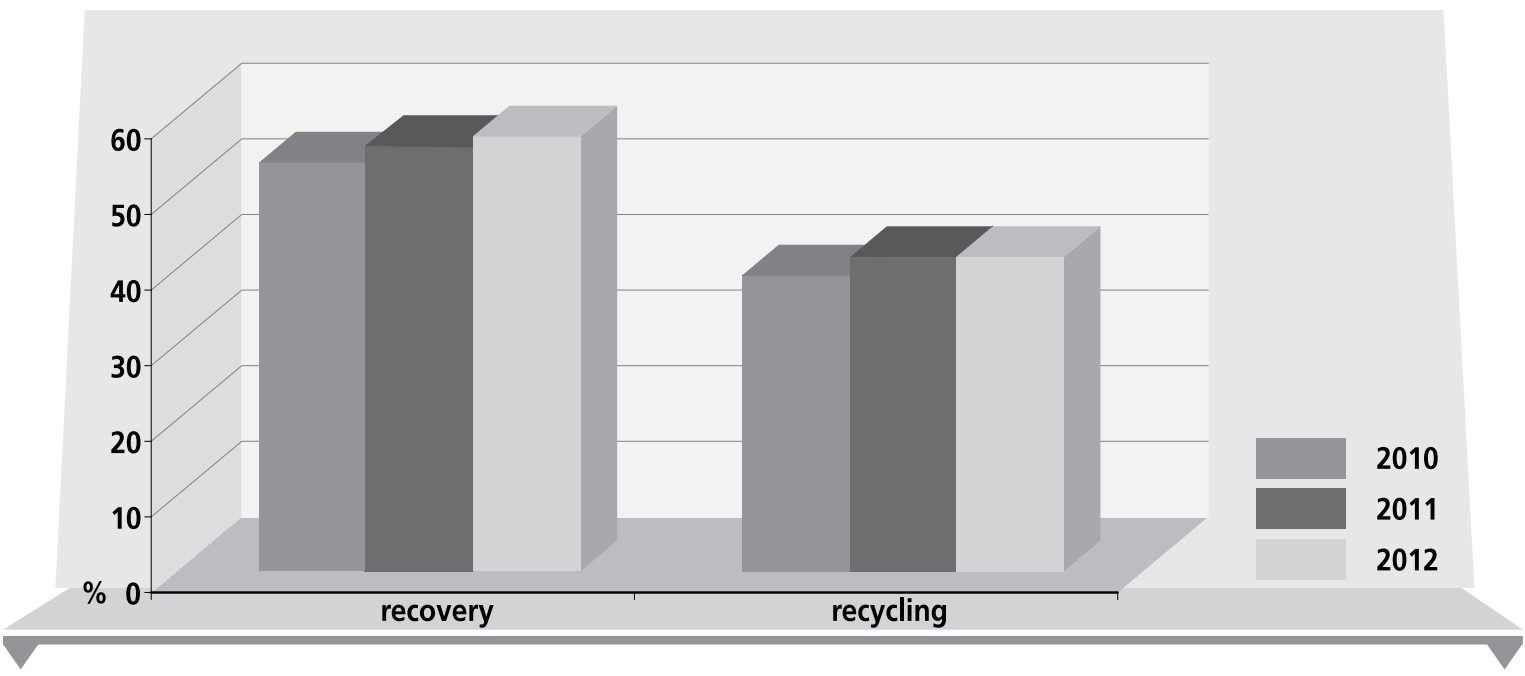

Figure 1. The achieved level of recovery and recycling of packaging waste for 2010-2012

Source: Author's own reseach based on Ochrona środowiska 2013. GUS, s. 562.

(Environmental protection 2013. CSO, p. 562) 
Figure 2 shows the required and achieved level of recycling of packaging waste in 2012. Required levels of recycling were achieved in the case of packaging waste: wood, hollow glass, steel and plastics.

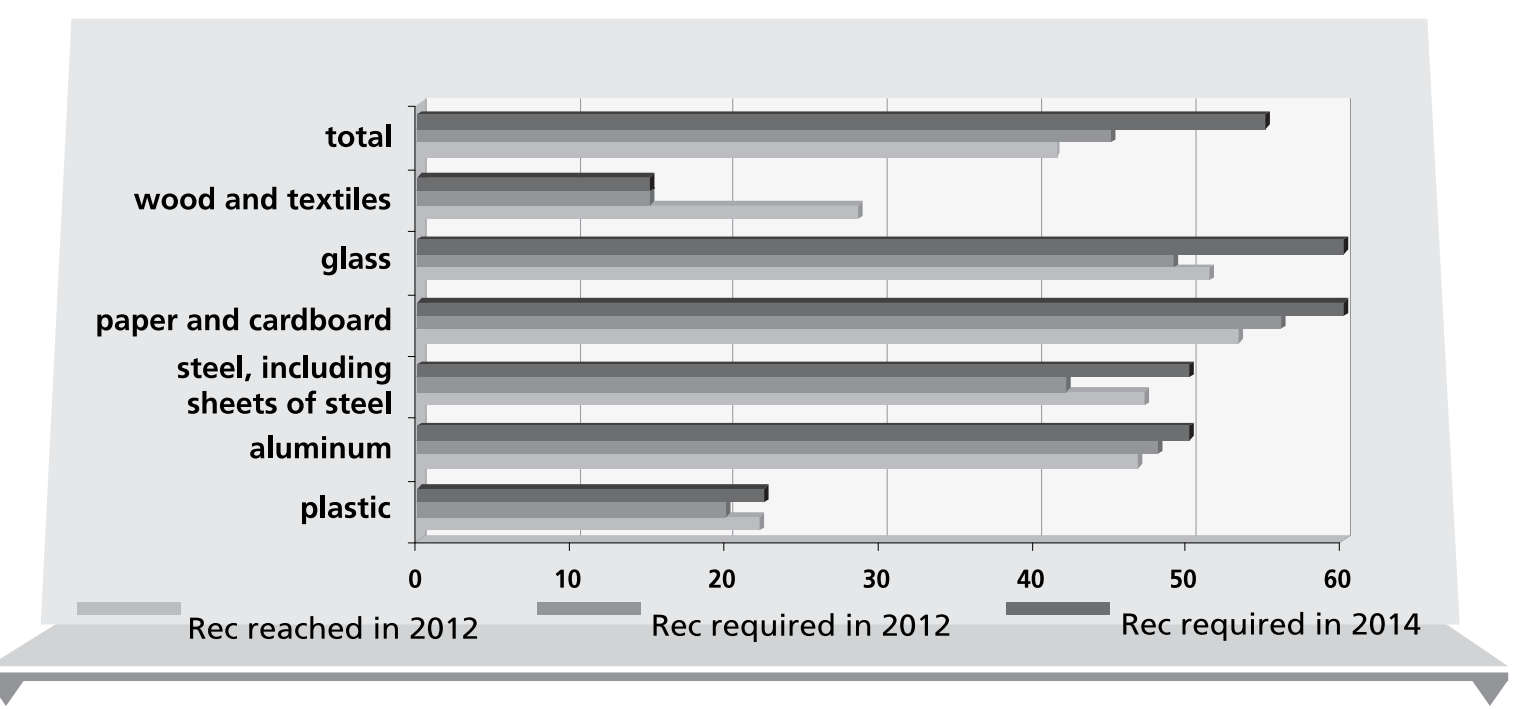

Figure 2. Required and achieved level of recycling of packaging waste in 2012

Source: Author's own resarch based on Ochrona środowiska 2013. GUS, s. 562. (Environmental protection 2013. CSO, p. 562)

Economic progress, globalization, changing lifestyles of inhabitants of the country, indirectly contributing to the increase or decrease in the minimum amount of waste. Although in recent years has been a slight decrease in the amount of waste (see GUS' data) it does not change the fact that the average level of municipal waste (including packaging waste) stands at over 12 million tons/year. Thus, the solution to the problem of proper municipal waste management is a priority objective for the Polish economy. New laws are intended to help to eliminate obstacles and accelerate the delivery of highly effective management of municipal waste. Increasing the level of recycling and reuse of waste as secondary raw materials and closing cycles in the economy will avoid depositing them in landfills. However, to do this you need a social acceptance of the changes, often changing habits and high environmental awareness. 


\section{The attitude of consumers resulting from lifestyle change - research results}

The packaging industry and packaging themselves occupy an important position in the economy of each country. According to A. Korzeniowski "nearly $90 \%$ of all products manufactured in the world requires the use of appropriate packaging. Relationship between packaging and modern technology and distribution organization, their impact on capacity utilization measures transport and warehouses and mechanization of cargo handling, as well as the importance of packaging in securing quality products make it necessary to look for modern packaging materials and packaging structures. Progress in the field of packaging is primarily based on improving their barrier properties, strength, resistance to aging, etc. while searching for new materials to solve the environmental problems" (Korzeniowski 2007, p. 5). Despite the availability on the market of many modern materials packaging, biopolymers, the amount of packaging waste that goes to landfill is very large.

Polish Chamber of Packaging estimated polish packaging market in 2013 at the level of 7.6 billion euros (32 billion zł), which was approx. 200 euros (840 zł) per capita. In 2008 packaging market value was estimated in the range of 4.2 billion euros. As you can see, within five years the packaging market's value nearly doubled. Despite this, the average Pole consumes about $35-40 \%$ less packaging than citizens of developed countries of Western Europe, USA, Japan. The structure of the domestic packaging market from the perspective of destination packages dominate the packaging for food and drink - about $65 \%$, at the second place is the packaging of industrial and household chemicals 22.2\% share (see tab. 3) (Wasiak 2014).

Table 3. The structure of the packaging market in terms of packages destination (data for 2013)

\begin{tabular}{c|l|c|c}
\hline NO & \multicolumn{1}{|c|}{ DESTINATION } & $\begin{array}{c}\text { MARKET } \\
\text { SHARE IN \% }\end{array}$ & $\begin{array}{c}\text { MARKET VALUE IN } \\
\text { MLD EURO }\end{array}$ \\
\hline 1. & packaging for food and beverages & 64,8 & 4,90 \\
\hline 2. & packaging for cosmetics and personal care & 6,0 & 0,46 \\
\hline 3. & packaging of medicines & 7,0 & 0,53 \\
\hline 4. & packaging of industrial and household chemicals & 22,2 & 1,71 \\
\hline 5. & TOTAL & 100 & 7,60 \\
\hline
\end{tabular}

Source: Wasiak 2014 
In 2006 European Commission published study (06 Sustainable consumption ...2006), which analyzed consumer attitudes resulting from lifestyle changes and their impact on the environment throughout the life cycle of the three areas of consumption. It was noted that $60 \%$ of consumer expense is devoted to: 1) purchase of food and beverages, 2) private transport, and 3) flat (including heating and hot water, electrical and structural work). Together, these three areas of consumption are responsible for $70-80 \%$ of the environmental impacts. Consumption of foods characterized by increasing consumption of processed foods and ready meals was associated with:

- crossing for shopping,

- energy consumption during cooking,

- storing food in the refrigerator,

- production of organic waste and packaging.

Increased food processing resulted in the increase of energy and material expenditure and also the increase in the amount of packaging waste.

As you can see the structure of the packaging market from 2013 (Wasiak 2014) overlaps significantly with the results of studies that relates to consumer behavior and the impact of their purchasing decisions on the environment. The priority in purchasing decisions, as in Maslow's hierarchy, are and will be food and drinks, or basic products, allowing survive.

Similar research on consumer attitudes, but in the direction of determining their level of environmental awareness, knowledge of the ecological marks and the resulting purchasing decisions, the author conducted in 2011-2014 among three years full-time and part-faculty students of Economics and Management, University of Zielona Góra. Every year 300 students were subjected to the study, so total of 1200 people were examined. Due to the nature of part-time studies (50\% of respondents) students in the age group of 19 to 48 years were participated in the study, student who live in not only the region of Lubuskie Province, but also come from neighboring provinces: Zachodniopomorskie, Dolnośląskie, Wielkopolskie and even Małopolskie, Śląskie or Germany (Brandenburg).

Environmental awareness is perceived by the author multifaceted and therefore is treated as a "discursive consciousness, which is closely correlated with the social one and refers to the ability to express certain ecological attitudes of cognitive, mental and axiological discourse, shaping it according to this vision of reality, and under its influence, and also the ability to see these discursive features that are not consistent with it, and their normative assessment" (Steciagg 2012, p.63). 
Research, both from the years 2011- 2013, as well as those of 2014 showed that respondents when purchasing goods in the order are directed primarily by: 1) price, 2) product quality, 3) brand, and the least important criterion was 4) ecological aspect and whether the package was marked or not ( $8 \%$ of responses). In addition, $54 \%$ of students claim to be environmentally conscious, but the consciousness is not reflected in their attitude. Only 58\% of respondents separate waste, $49 \%$ know the markings on the containers for segregation, $15 \%$ did not see the need for segregation, $21 \%$ admit to a lack of segregation habit, $21 \%$ of no time for segregation, $80 \%$ of respondents believe that changes in the economy management still need at least five years of education and changes in the system (see figure 3; part of the study will be published in Zarębska 2014).

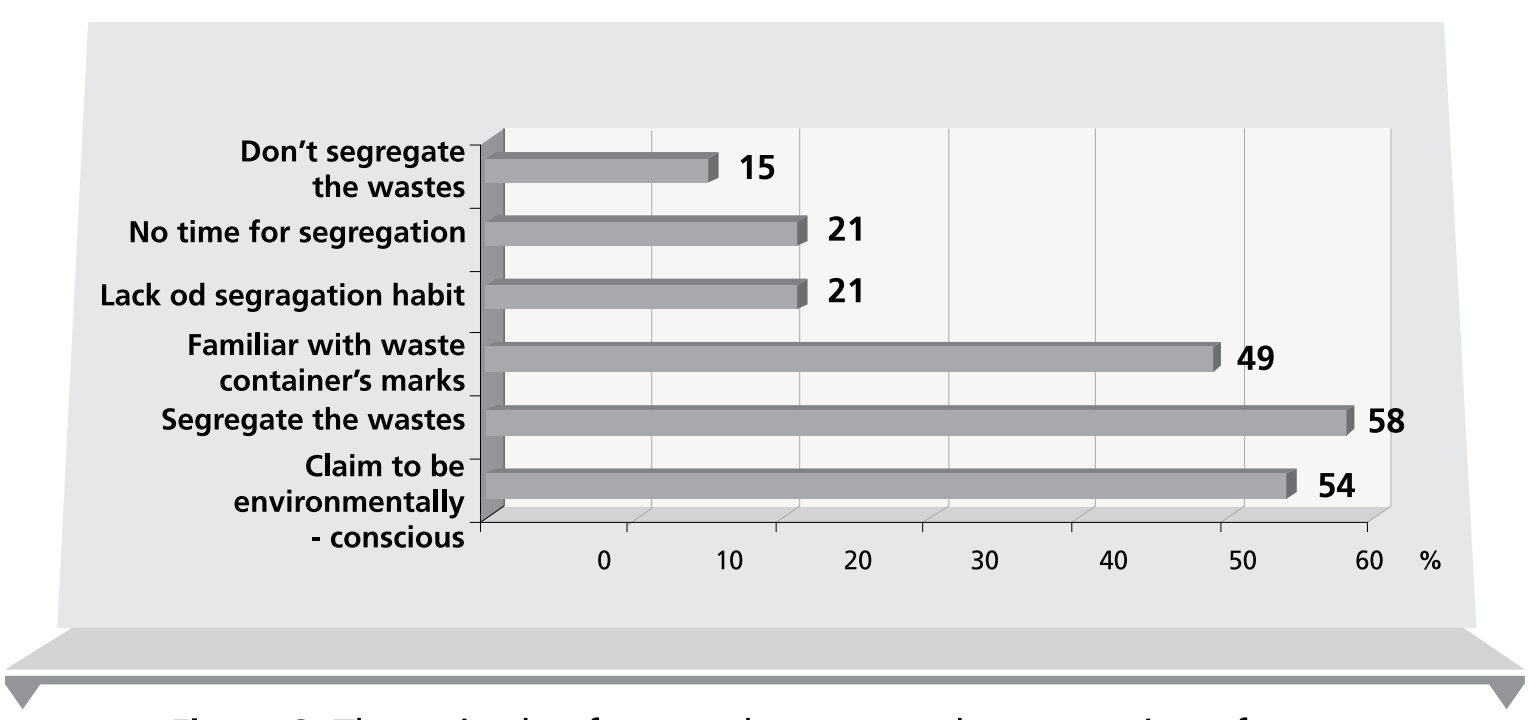

Figure 3. The attitude of respondents towards segregation of waste

Source: based on Author's own research

Changing consumer shopping trends manifests an increase of (Zarębska 2004):

- interest in highly processed foods, designed for quick preparation (e.g. in microwave),

- requirements for good quality products, safe, nutritious, no preservatives, dietary, light with packaging of which will be constantly updated, comfortable to use,

- the demand for small, single servings or sets of different products placed in the same package, 
- the use of reusable packaging, undergoing biodegradation in the environment and "edible",

- ready meals, for example.

Chinese or Vietnamese in disposable packaging ready for heating, indirectly cause an increase in the diversity of waste packaging. Taking into account the results of research that only $58 \%$ of respondents separate waste, it can be concluded that the remaining $42 \%$ do not segregate their waste and municipal waste as mixed waste going to landfills. Mixed waste landfills require additional segregation of secondary so additional costs incurred by the City of Municipal Markets. Such actions result in a reduction in the efficiency of waste management and out to the required levels of recovery and recycling of packaging waste.

From studies of nationwide TNS Poland from 2014 it can be concluded that the importance of segregation of waste is in education of respondents. Nationwide survey showed that "most skeptics of the new law junk (52\% -59\%) among respondents aged 30-49 years with primary degree and living in urban areas with population to 20 thousand. More supporters of the new law is among people with higher degree (43\%-49\%) and those living in large cities of 100 thousand to 500 thousand. residents" (http://www.stefczyk...).

It seems that continuous ecological education and campaign for sustainable production and consumption and resource management is important to change the negative attitudes to the new Waste Act is. The analysis of these studies show a large and continuous need for action aimed at raising environmental awareness of consumers / society (especially the less educated), information on proper handling of packaging waste take-back systems, recovery and recycling of waste and its impact on the environment. The universality of communication or information campaign in the mass media (radio, television, Internet), the availability of brochures, posters and events of information and education are very important.

\section{Summary}

The new Directive COM (2014) 397 final requires from Poland increasing the efficiency of municipal waste management system and achieving better results in terms of waste management in general. Changing consumer trends adversely affect the implementation of the requirements of acts set by causing an increase in the amount of waste packaging. Although according to CSO data, the level of municipal waste generated has stabilized in recent years, but this packaging waste are the most diverse group in terms of municipal waste material and 
therefore require to carry out segregation "at source" that is, the point of origin (in homes, offices, cinemas, warehouses, etc.).

Increasing efficiency of waste management in Poland is a necessity due to the systematic growth of the packaging market in the country. According to the forecasts of the Polish Chamber of Packaging at the rate of economic growth of 4\%-5\% in 2014-2020 packaging market will reach approx. 300 euros per capita, which is comparable to that of developed markets of Western European countries.

Environmental awareness affects in more efficient waste management system (especially packaging). The increase in the efficiency of waste management is proportional to the growth of education (TNS Poland studies), and therefore there is a need for continuing education in this field. The need for continuous environmental education, education discursive, indicate the results of the author's research, which shows that $54 \%$ of respondents claims to be environmentally conscious, $49 \%$ were familiar with the markings on the containers for waste segregation, and yet only 58\% of them separate waste. According to Eurostat data in Germany and Belgium almost $100 \%$ of the citizens segregates waste in the Czech Republic - 76\%, Slovakia - 63\%, and in Poland only 37\% (http: //odpady. nfosigw.gov.pl ...). So it can be assumed that the greatest barrier in increasing the level of segregation of waste is the human factor, and this binds him with: awareness, knowledge, skills and habits.

\section{Summary}

Packaging waste in Poland - current status and perspective The article presents the results of research, whose aim was to answer the question of how changing consumer trends affect the implementation of the requirements of the Waste Act and the Act on packaging and packaging waste. The new EU directive enacted in July 2014 tightens the requirements towards waste management in the EU, and this is especially evident in the increased levels of recovery and recycling of packaging waste. Surveys performed among students showed a high correlation between ignorance in the recovery and recycling of packaging waste and increasing level of efficiency in waste management. Surveys conducted among students and analysis of literature data show the relationship between environmental awareness of respondents and the level of effectiveness in the management of packaging waste.

Keywords: $\quad$ waste, medicines, direktive COM(2014) 397 final. 


\section{Streszczenie}

\section{Gospodarowanie odpadami opakowaniowymi w Polsce - stan obecny i perspektywa}

W artykule zaprezentowano wyniki badań, których celem było uzyskanie odpowiedzi na pytanie $\mathrm{w}$ jaki sposób zmieniające się trendy konsumpcyjne wpływają na realizację wymagań ustawy o odpadach i ustawy o gospodarce opakowaniami i odpadami opakowaniowymi. Nowa dyrektywa UE uchwalona w lipcu 2014 roku zaostrza wymagania wobec prowadzonej gospodarki odpadami $w$ krajach UE, a szczególnie jest to widoczne w zwiększonych poziomach odzysku i recyklingu odpadów opakowaniowych. Badania ankietowe przeprowadzone wśród studentów oraz analiza danych literaturowych wykazują zależność pomiędzy świadomością ekologiczną ankietowanych a poziomem efektywności $w$ gospodarowaniu odpadami opakowaniowymi.

\section{Słowa}

kluczowe: odpady, lekarstwa, odzysk opakowań, dyrektywa COM(2014) 397 final.

\section{References}

1. 06.Zrównowazona konsumpcja i produkcja (2006), (06. Sustainable consumption and production), website: www.eea.europa.eu/pl/ publications/ srodowisko-europy.pdf (20.09.2014 - date of access).

2. Dyrektywa Parlamentu Europejskiego i Rady z dnia 2 lipca 2014 roku COM(2014) 397 final, 2014/0201 (COD) zmieniająca dyrektywy 2008/98/WE w sprawie odpadów, 94/62/WE w sprawie opakowań i odpadów opakowaniowych, 1999/31/WE w sprawie składowania odpadów, 2000/53/WE w sprawie pojazdów wycofanych z eksploatacji, 2006/66/WE w sprawie baterii i akumulatorów oraz zużytych baterii i akumulatorów i 2012/19/UE w sprawie zużytego sprzętu elektrycznego i elektronicznego, Komisja Europejska, Bruksela.

3. EEA Report No 2/2013. Managing municipal solid waste - a review of achievements in 32 European countries, website: http:/ / www.eea.europa. $\mathrm{eu} /$ publications/managing-municipal-solid-waste (08.08.2014 - date of access).

4. Korzeniowski A. (red. nauk.) (2007), Innowacyjność w opakowalnictwie, Zeszyty naukowe nr 93, Wyd. AE w Poznaniu, Poznań.

5. Korzeniowski A., Skrzypek M., Szyszka G. (2001), Opakowania w systemach logistycznych, Biblioteka Logistyka, Poznań. 
6. Ochrona Środowiska 2013, Główny Urząd Statystyczny, Warszawa 2013, website: ttp://old.stat.gov.pl/cps/rde/xbcr/gus/SE_ochrona_ srodowiska_2013.pdf (08.09.2014 - date of access).

7. Plan dziatania na rzecz zasobooszczędnej Europy COM(2011) 571 final, (Roadmap to a Resource Efficient Europe COM(2011) 571 final), Europejski Komitet Ekonomiczno-Społeczny, Bruksela 2012, website: http:/ / eur-lex. europa.eu/LexUriServ/exUriServ.do?uri=COM :2011:0571:FIN:PL:PDF (20.09.2014 - date of access).

8. Rozporządzenie Ministra Środowiska z dnia 12 marca 2014 r. w sprawie rocznych poziomów odzysku i recyklingu odpadów opakowaniowych pochodzących z gospodarstw domowych (Dz. U. 2014, poz. 412).

9. Rozporządzenie Ministra Środowiska z dnia 16 kwietnia 2014 r. w sprawie minimalnych rocznych poziomów odzysku i recyklingu dla opakowań wielomateriałowych oraz dla opakowań po środkach niebezpiecznych, w poszczególnych latach, poniżej których nie mogą zostać określone poziomy w porozumieniu zawieranym z marszałkiem województwa (Dz. U. 2014, poz. 618).

10. Rozporządzenie Ministra Środowiska z dnia 29 maja 2012 r. w sprawie poziomów recyklingu, przygotowania do ponownego użycia i odzysku innymi metodami niektórych frakcji odpadów komunalnych (Dz. U. 2012, poz. 645).

11. Steciąg M. (2012), Dyskurs ekologiczny w debacie publicznej, Oficyna Wyd. Uniwersytetu Zielonogórskiego, Zielona Góra.

12. Website: http://www.stefczyk.info/wiadomosci/raporty-stefczyk-info/ polacy-nie-chca-segregowac-smieci,8065859332 (20.09.2014 - date of access).

13. Website: http://odpady.nfosigw.gov.pl/gfx/odpady/userfiles/files/10 spotkanie/1_ersntyoung_sudomir_prezentacja_26042012.pdf (20.09.2014 - date of access).

14. Ustawa z dnia 1 lipca 2011 r. o zmianie ustawy o utrzymaniu czystości i porządku w gminach oraz niektórych innych ustaw (Dz. U. 2012, poz. 391).

15. Ustawy z dnia 11 maja 2001 r. o obowiązkach przedsiębiorców w zakresie gospodarowania niektórymi odpadami oraz o opłacie produktowej (t.j. Dz. U. 2007, nr 90, poz. 607 ze zm.).

16. Ustawa $z$ dnia 13 czerwca 2013r. o gospodarce opakowaniami i odpadami opakowaniowymi (Dz. U. 2013r., poz. 888).

17. Ustawa z dnia 14 grudnia 2012 r. o odpadach (Dz. U. 2013, poz. 21 ze zm.).

18. Wasiak W., Przemyst i rynek opakowań w Polsce. Raport. Polska Izba Opakowań, website: http:// magazynspozywczy.com.pl/raporty/ przemysl-i-rynek-opakowan-w-polsce (25.09.2014 - date of access). 


\section{Management \\ 2014}

Vol.18, No. 2

19. Zarębska J. (2004), Algorytmy bilansów ekologicznych wybranych opakowań, Wydział Towaroznawstwa, AE w Poznaniu, rozprawa doktorska.

20. Zarębska J. (2013), Ekologiczne i ekonomiczne aspekty gospodarki odpadami opakowaniowymi w województwie lubuskim, Oficyna Wydaw. Uniwersytetu Zielonogórskiego, Zielona Góra.

21. Zarębska J. (2014), Ecological product marking a youth environmental awareness, "General and Professional Education", nr 4 (print article).

Packaging waste in Poland - current status and perspective 